\title{
Democratic Transition in Mexico: Case of City Juárez
}

\author{
Sergio Pacheco González \\ Universidad Autónoma de Ciudad Juárez, Ciudad Juárez, Mexico \\ Jesús Alberto Rodríguez Alonso \\ Universidad Autónoma de Ciudad Juárez, Ciudad Juárez, Mexico
}

\begin{abstract}
The electronic and bibliographic sources, as well as some interviews and focus groups conducted in Ciudad Juárez, Chihuahua, all present interpretations by different actors on the so-called democratic transition in Mexico. The model, proposed Carothers (2002) to explain the transition from a dictatorship to democracy, as stage universally. This article shows which of the five assumptions of the model are present in the experience of the Mexican transition and those that were not consider applicable. He also argues that the model shows features of a teleological perspective, by omitting the particularities of each country, eliminating any reference to diversity and difference, becoming an ideological approach linked to the process of economic globalization. It criticizes the absence of discussion of social and economic objectives that should be priority in a conception of substantive democracy, rather than limiting the horizon of the transition to a liberal and normative conception, that assumes two basic formulas: (1) Democracy is equal to elections; and (2) a citizen is a vote. Contrasting documents on electoral disenchantment in Ciudad Juárez and the actions that various political actors have done, we can illustrate what can be termed substantive citizenship.
\end{abstract}

Keywords: democratic transition, authoritarianism, electoral democracy, liberalization, political regime

\section{Introduction}

In June 5 of 2016, 12 States of the Mexican Republic held elections; the Partido Acción Nacional (National Action Party, PAN) won seven governorships, including that of Chihuahua, for the second time in history. As head of a note of the day on June 7, the Partido Revolucionario Institucional (Institutional Revolutionary Party, PRI) lost for the first time, "four historical bastions": the States of Veracruz, Tamaulipas, Durango and Quintana Roo. Of these four, the PAN gets Tamaulipas with own candidate, the other three in alliance with the Partido de la Revolución Democrática (Party of the Democratic Revolution, PRD) and in addition to Puebla in alliance with the Partido del Trabajo (Labor Party, PT).

The Chihuahua experience stands out not only for expressing a new episode of alternation in the governorship between PRI and PAN - the first had place in 1992. The 2016 election exceeded the results of the democratic insurgency of the 1980s, when PAN wins elections in the mayoralties of Juárez, Chihuahua, Delicias, Camargo, Parral and Meoqui, while the Partido Socialista de los Trabajadores (Socialist Party of the Workers, PST) and the Partido Socialista Unificado de México (Unified Socialist Party of Mexico, PSUM) obtained Cuauhtémoc and Zaragoza respectively.

Sergio Pacheco González, Professor, Instituto de Ciencias Sociales y Administración, Universidad Autónoma de Ciudad Juárez. Jesús Alberto Rodríguez Alonso, Professor, Instituto de Ciencias Sociales y Administración, Universidad Autónoma de Ciudad Juárez. 
There has been also in this century the alternation in the Presidency of the Republic, with two successive mandates of holders of Executive Power emanating from the PAN and the PRI back in 2012, in a context marked by the homicidal violence and violation of human rights in various States. Tlataya and Ayotzinapa are just two of their expressions.

Ciudad Juárez, designated as the city most violent in the world in recent years, is head of one of the municipalities where the alternation had his first experiences in Mexico. It is one of the reasons why it is of interest to reflect on the so-called democratic transition.

\section{The Model of Democratic Transition}

The purpose of this section is to show items relevant of the prescriptive model called democratic transition, as well as speech that several Mexican intellectuals employed in public discussion and academic in relation to the Mexican experience, allowing post festum, equate it with the model predicted, specifying its content, and show disagreements about its periodicity on completion and pending tasks.

To illustrate the model of the transition, the article of reference is of Thomas Carothers, The End of the Transition Paradigm (2002), where he offers his interpretation of what Samuel Huntington called the third wave of democracy. He identifies democratization processes in seven different regions of the world and in several countries during the decades of the 1970s to 1990s processes including the demilitarization of the South America, the fall of the Communist order or the decline of authoritarianism in East and South Asia, among other experiences.

For this author, the explanation of this set of facts is argued in the administration of Ronald Reagan, through an analytical model of the structure of the transition to democratic. This are derived from the initial work in the academic field of transitology, from the early works of Guillermo O'Donnell, Philippe Schmitter and Laurence Whitehead (1988). Brewing is a group of promoters of democracy ${ }^{1}$ that from the experience of the countries of Eastern Europe, the Soviet Union and Africa have tried to extend this model as a universal paradigm of democratization.

However, Carothers perceived exhaustion model, in such a way that countries are in transition actually thought they were not, which meant recognizing that the model was no longer useful. To show it, we subject to review five assumptions that underpin the considered paradigm of transition: (1) That A country moves from its dictatorial role (political liberalization) always does to democracy; (2) The transition tends to develop in a series of stages or phases: a period of democratic agitation and political liberalization opens with the failure of the old regime and the emergence of a new one, holding elections and establishing a democratic institutional structure. This is often through the release of a new constitution, to achieve the consolidation, by setting new rules of democracy through reform institutions, to regularize elections, strengthening civil society and society adapt to the new democratic order; (3) The decisive importance of the elections, in such a way that the current formula is to consider that democracy equals elections, becoming the key to the successive democratic reforms. (4) The transition does not require covering specific preconditions in terms of economic level or legality of the institutions; and (5) the assumed democratization process as the redesign of state institutions, which includes creation of new electoral institutions, parliamentary reform and judicial reform.

\footnotetext{
1 This group of promoters could include the Agency of the United States for international development (USAID), which has sponsored democracy and governance in two editions, 2004 and 2006, through its program of Public Opinion in Latin America (LAPOP) project.
} 
Carothers's critique focuses on identifying inconsistencies in approximately one hundred countries who considered themselves engaged in democratic transition processes, of which about 20 countries could be within a dynamic that could place them in the process of consolidating itself as prosperous democracies. In his view, most countries was in what he calls a political gray zone characterized by the presence of attributes associated with democratic politics, as the existence of a limited participation of opposition political parties space and independent civil society, as well as regular elections and democratic constitutions. However, they have deficiencies in citizen participation beyond voting, government abuse and uncertainty about the legitimacy of the elections, which would place them outside the category of polyarchies ${ }^{2}$. In addition, Sánchez (2008, p. 10) mentions the institutionalization of multiple centers of power where the essential is the competition between the government and the opposition, the electoral way leaving aside the construction of the citizen

The relevance of the interpretation of Carothers is that it highlights the contradiction of the principles of political liberalism in an environment where economic liberalization is established as a global standard. For example, assuming pointing unnecessary to have economic or institutional preconditions to start the process of democratization, it is contrary to previous literature associating the possibility of establishing democracy only when the process of industrialization has promoted achieving higher levels of development. In this sense, there was talk of developing countries.

The bases of the conception of the process of democratization as a series of stages, is in its ideological load and its teleological character, which is criticized later. In fact, any reference to the Revolution concept disappears. In this regard, it is worth considering the judgment made by Claudio Lomnitz in the discussion organized by the Fractal Magazine (1999), which shares ideas with Roger Bartra and Jorge G. Castañeda:

Unlike the end of revolution, the transition is associate $d$ the vision of a process that has a peaceful sense of one way or another. In general, the revolutions generate an initial phase of openness and experimentation in which multiply and diversify the social controls. This phase is followed by another in which dominates the repression and terror. It happens in all or almost all revolutions. When it comes to transition anyone, imagine something similar. What you imagine is a step from point $\mathrm{A}$ to point $\mathrm{B}$; and point $\mathrm{B}$ is associated with a stable result. Change from authoritarian system to a democratic system, say, is an ending that looks like a sort of stable opening.

Similarly, the premise that the political changes in dictatorial countries necessarily lead to democracy implies a risk: "The persistent use of paradigm transition is a dangerous habit to try to impose a simplistic conceptual order and often incorrect on an empirical picture of considerable complexity" (Carothers, 2002, p. 15).

Meanwhile, the currency notes that it is more democratic while most are free and fair electoral processes, which can include discussion related to the field of politics and the conception of democracy that is part. For example, the two dimensions of political expression, are relative to the power relations that take place in society; and the others are relative to those that are the subject of the state, the government and the enactment of laws. In the same vein, referring to democracy, Bobbio (2002) distinguishes between real democracy and formal democracy, referring to the second to liberal democracy, defined as legal-institutional and procedural nature, design comprising the base law, equal opportunity, where equality:

\footnotetext{
${ }^{2}$ Robert Dahl (1996) distinguishes between closed hegemonies, representative hegemonies, competitive oligarchies and polyarchies, differentiating this last denomination with two aspects of importance. That regime does not exist any "of considerable dimension" that could be considered fully democratic and that integrate this category those countries whose political systems offer the best conditions for liberalization, understood as access to public debate, and participation, in terms of the representation of the various interests.
} 
...for the good functioning of democracy,... participation in the vote can be considered as the correct and effective exercise of political power, or of the power of influencing the taking of collective decisions, only if it is done freely. For example, if the individual who goes to the polls to defray enjoys the freedoms of opinion, of press, and of association, of all the freedoms that constitute the essence of the liberal State, and that as such act as necessary budgets so that participation is real and not fictitious. (p. 47)

With regard to institutional reform, one can observe some inconsistency with the assumption of the absence of specific conditions regarding the legality of the institutions, while involves precisely the existence of an ideal model to which must gird whatever the peculiarities of the countries in the process of democratization. To whom the initial question about reforms would be? What reforms are supposed? It is responsible for the pre-existence of a dictatorial state. In order to illustrate the application of this paradigm, we set to the discussion about the democratic transition that took place in the years before the Mexican experiences the alternation it made.

\section{The Democratic Transition in Mexico: Content and Timing}

This section is required, from the document review, what political analysts spoke when they prepared their speeches about the democratic transition in Mexico: what conception of democracy their own, which temporality and what their similarities are with the model Carothers points out as the paradigmatic in this area. We proceed according to the order in which their assumptions are previously presented. That is to say, it assumed transition from dictatorship to democracy, which linked directly with the second case, on its stages, the failure of the former regime and liberalization policy, to move to the tendency for equating democracy elections, discuss the course of the lack of preconditions and conclude with the relevant redesign of state institutions.

\section{Transition from Dictatorship to Democracy: One Supposed}

One aspect to consider, and already noted by Carothers, is the diversity of countries to which it intends to apply the same model. Which is considered involves identifying the dictatorship as the condition from which the process begins without making appropriate distinctions between military, single party or hegemonic party regimes, enabling the emergence of an ideological discourse that hinders the full understanding of the scope of the model. In this regard, it is possible to observe how different analysts agree to name the Mexican regime in the starting stage of the transition process.

For example, Rafael Farfán (1996) parts of a generalization by which replaces dictatorship authoritarianism. He considered that "transition is understood today as 'the interval between one political regime and another', by which one moves from an authoritarian-exclusionary regime to a democratic pluralist one that starts with a crisis of the first" (p. 25). The concept of transition as a process involving a change of regime, the characteristic of authoritarian and condition of uncertainty feature - the latter also shared by Farfán - is presented by Durand Ponte (2004), who said "The transition process refers to regime change, to the end of authoritarianism ..." (p. 31).

To clarify the content of the concept of regime and elaborate on this concept of Mexican as authoritarian, useful definition that makes O'Donnell:

... The articulation (assembly) of patterns, explicit or not, that determine the forms and channels of access to the main positions of government and the characteristics of the actors that are admitted and excluded from those accesses, as well as the resources and strategies that they can use to access them. (Durand Ponte, 2004, p. 22) 
This definition allows us to understand better judgments presented above, as well as signs that perform Molinar Horcasitas (Kuschick, 1996a, pp. 22-23), Jesús Silva-Herzog Márquez (2004, p. 18) and César Cansino (2004, p. 36). For whom the Mexican regime characterized by authoritarianism, he expressed in the following attributes: tolerated and legal opposition, noncompetitive, civil, presidential regular elections, centralist, with institutional continuity, inclusive, corporate and hegemonic party.

As you can see, these elements prefigure patterns of access to positions of power, among which are, from the perspective of Molinar Horcasitas, exercising its repressive capacity (although to a lesser extent than in other countries) and the exercise of corruption. Silva-Herzog (2004) for the feature set condensed in the hegemonic "essential to qualify Mexican authoritarianism" (p. 41).

From these observations, it is possible to reach a conclusion regarding the first model of democratic transition in the Mexican case, except anecdotal references that give rise to such expressions as perfect dictatorship $^{3}$, considering the Mexican regime as authoritarian. It is pertinent to quote Macario Schettino on the text of Daniel Cossio Villegas, La crisis de Mexico. In their collaboration to collective book defined the regime as corporate and authoritarian, stating: "A corporate regime is authoritarian, but sustains its political control more in negotiation than in repression..." (Schmidt, 2003, p. 127) coinciding with one of the features identified by Horcasitas.

\section{Stages or Phases the Transition}

The second assumption, that the transition tends to develop in a series of stages or phases, is widely shared by many analysts, including those mentioned above, although there is not the same agreement as regards their frequency. In this regard, it is necessary precisely to the failure of the regime that opens the period of upheaval and democratic liberalization budget. This is because that the model approach does not clarify timely if this expression refers to the social, economic and/or political failure of the regime. However, if it adheres to the notion of regime above indicated, the consideration of a period of democratic agitation and course room, indicate that the transition doesn't requires covering specific preconditions in terms of economic level or legality of the institutions. He would have to conclude its conceptualization not linked, directly, to socio-economic, but political, as could be the loss of legitimacy of the regime. Then it shows in what dimension of reality analysts placed the beginning of this process for the Mexican case.

Thus, coincident with the notion of process, Farfán (1996) took into account two stages. The first of which corresponds to liberalization stage where "a 'compromise rupture' or 'negotiated reform" takes place and where "The democracy thus achieved is, more than anything, the result of a calculated design between elites and not a historical process of maturation or a certain type of starting conditions..." (p. 25) from your perspective, transit from one stage to another-it occurs in a context of stability, as the lines indicated above by Lomnitz are in line with the fourth course without any prerequisite.

This is not the position of Horcasitas and it's not by an element that seems substantial. He answers a question on the adjective democratic politics replacing the interviewer, Murilo Kuschick. The question is in 1996: Mexico is located in a process of political transition. His answer is very relevant to introduce the elements that explain this democratic agitation:

\footnotetext{
${ }^{3}$ Expression used by the Peruvian writer Mario Vargas Llosa, in one of his visits to Mexico in 1990, which resulted in a controversy that affected its image at home and away from it. In 2006, he returned to refer to the Mexican political regime, now in Spain, qualifying it as an imperfect democracy.
} 
I believe so, because the transition has two sides: a destructive and a constructive part. The first is the final crisis of the old Mexican political system with economic and political roots that really have no remedy ... Now there is also a productive, creative, constructive part of the political transition in Mexico. The political power that loses the PRI is finally strengthening new institutions, other parties - for now basically the PAN, but also the PRD; Is generating a different distribution of power in the country, pluralizing the structures of power and forcing the regime to seek reforms to adjust to the new times, and all this as a creative process. A new regime constructed at the same time as the former destroyed. (Kuschick, 1996b, pp. 221-222)

Ponte also considered relevant economic conditions in which the system operates: "In the Mexican case... the transition from authoritarian to democratic regime occurred in the context of a long economic crisis, from the mid-1970s to the present day" (2004, p. 19). However, from the perspective of political culture, which is its field of analysis, the economic dimension is not the only variable to consider and, coinciding with the views expressed by Farfán, said, "The political culture of the masses does not have the capacity to make or provoke a regime change. It would seem that the transition requires two permanent elements: a crisis and the strategic action of the elites" (Durand Ponte, 2004, p. 18).

Similarly, Silva-Herzog expressed, considering that "The centrality of elites comes from the fact that transitions to democracy are negotiated" (2004, p. 130). And this is important to specify what kind of elites it is referring to the analyst, especially because his analysis is done through a trial on civil society. "The politically correct version of the transition sings that the sign of change is the flowering of civil society... but I think if you look at things from another side, the great novelty of our time is the protagonism of political parties" (2004, p. 93). In this change of relevant actors and institutions, it is pertinent to observe the different classifications or periodization concerning the transition, as a process of transformation, although not necessarily linear, from authoritarianism to democracy going through the stages of liberalization.

For this purpose, it should be recalled that Mexico lived after the institutionalization of the revolutionary process of the early 20th century until November 2000. Mexico was under the administration of rulers who exercised the Federal Executive power and for a long period of time state (until 1989) and municipal by members of the Partido Revolucionario Institucional (Institutional Revolutionary Party, PRI, founded in 1946) and their organic predecessors - the Partido Nacional Revolucionario (National Revolutionary Party, PNR in 1929) and the Partido Mexicano de la Revolución (Party of the Mexican Revolution, PRM, in 1938).

The PRI, as the hegemonic party, was the instrument of the Mexican political system to organize various social, economic and political sectors through corporatism and management of the circulation process of local, state and national leaders. Called by itself, as the party of the Revolution, he was considered heir and representative of the values and promises that the movement had established as its flags and objectives. The work of various leaders and organized groups, supported by the ideology of revolutionary nationalism, led the country in the process of modernization ${ }^{4}$ and erected the institutional structure that gave cohesion and educational work that, despite the differences within a multicultural society, built a national identity. The regime, not without conflict, manages to consolidate and be accepted by large groups of people. However, depletion of the development model and vices in the struggle for power undermined the legitimacy of the regime.

\footnotetext{
4، Between 1940 and 1980 the economy grew to a rhythm annual of $6.4 \%$ and the participation of the industry manufacturing in the product is raised from $15.4 \%$ to $24.9 \%$. The urban population increased from $35 \%$ to $66 \%$ and the total population nearly quadrupled from 20 to 70 million; literacy rates have doubled, reaching $83 \%$; half of the adult population schooling rose from 2.6 to 4.6 years and the life expectancy at birth increased from 24 to 65 years (INEGI, 1985)" (Bayón, 2006, p. 137).
} 
I noted about the prospects of Durand and Horcasitas, several more are in the economic dimension reasons for the crisis of the regime occurred. For example, Silva-Herzog (2004) refers to what we can point to as the social pact based in the post-revolutionary regime:

In speaking of transition we emphasize that this rare creature born of the Mexican revolution, which hid under consensual forms its democratic nature no longer exists... the title of revolutionary legitimacy was broken; the economic and political agreements that recreated the consensus collapsed; Traditional rules are violated on a daily basis. (p. 53)

Meanwhile, an analysis of the economic policy by Leon Bendesky of the last 30 years of the last century, incorporates the views of Raymond Vernon (El dilema del desarrollo económico de México) and Gonzalo Robles (Noticias sobre la industrialización de México). To account for two of the assumptions made by Cosio Villegas in the text already mentioned, the increasing dependency relationship with the US and the transfer of political power to the right of the political spectrum, Schmidt (2003) states, "It was not until 2000 that the PRI lost the elections to the PAN; but then, the social and economic program which had been imposed since the mid-1980s was no different from the one proposed by the right, and this seems to have been its heir" (p. 93).

The other dimension of the crisis-political crisis, coupled to the blurring of the then hegemonic ideology and the conflict that exists between the party elites. While Durand remember that your prospect is the political culture that "there has never been anything resembling a crisis of legitimacy", we cannot ignore a series of events that shape the context and the peculiarity of the presidential election of 1976 and as subsequent shocks experienced by the political class 5 .

\section{Importance of the Elections, the Key to the Successive Democratic Reforms}

Thus, the emergence of student movements of 1968 and 1970 related to the authoritarian features of the regime and the repression to which they were subjected, which influences the proliferation and growth of the guerrilla, urban and rural groups. The political crisis presented to the president Luis Echeverria Alvarez ${ }^{6}$ and the devaluation of the currency at the end of his term, express their importance in the political arena as the candidate of the PRI, José López Portillo. She was forced to introduce the election process as the sole candidate. In this regard, he noted Paramio that one of the problems that Jesús Reyes Heroics, Secretary of the Interior in the period of López Portillo would confront is:

... The lack of legitimacy that had meant for López Portillo to be chosen as a single candidate, although the main cause would have been the lack of internal agreement in the PAN - at its Extraordinary Convention of January 25-to designate its own presidential candidate 1976. (FRIDE, 2002, p. 6)

As above, the prospect of internal dissent in the ranks of PAN has been the main cause of the delicate situation in which the then PRI candidate was not shared. In this regard, José Woldenberg, recognizing the importance of the armed movements in that period says:

\footnotetext{
5 In the same sense the interviewer of the Fractal magazine (2002), is expressed for those who "Unlike transitions 'classicals' Spain, Portugal and Greece, the process that was initiated in 1988 has not been exactly peaceful. The Chiapas conflict and the growth of the guerrillas realize this".

6 A short excerpt from a speech given by Luis Echeverría Álvarez nearly concluded its mandate, gives a clear idea of the conflict that was developing between the political class and the economic elite: "This is a calm and democratic meeting. I proposed that it be held with representatives of all States and all national economic activities as an open and democratic response to a clandestine, profascist and anti-Mexican meeting held a few weeks ago in Monterrey". Discurso en la Inauguración de la Reunión Nacional sobre Asentamientos Humanos, Museo de la Ciudad de México, $1^{\circ}$ de abril de 1976.
} 
By a typical historical irony, despite the effervescence of the dissidents, the 1976 presidential election won by the only registered candidate, José López Portillo, of the Revolutionary Institutional Party. The reality left no doubt: Mexico had a single party that owned 100 percent of the effective vote. The National Action Party was not in a position to present an alternative because $t$ strong internal crisis and the Mexican Communist Party remained artificially excluded from the legal contest. It is important to reiterate the contrast: in 1976, just when the country is crossed by an increasing and expansive conflict, the presidential elections turn out to be little more than a formalism. A single candidate, a single option, a single campaign, in a convulsed, closed and aggrieved country. (FRIDE, 2002, p. 34)

The assumption of the crisis of legitimacy, means that the electoral reform of 1977 and the work done by Jesús Reyes Heroics is recognized, considering the last ideologue of revolutionary nationalism. Legitimacy, not legality, from office and the regime itself was in question, according to Silva-Herzog (2004):

The design of Reyes Heroles defined the electoral agenda and, largely, the political agenda of the following decades... the change would have to focus on the transformation of two knots of the regime: the form of turning the votes into seats in the Congress and the integration and functions of the electoral authority. (p. 56)

This electoral reform, which gives rise to the Federal Law of Political Organizations and Electoral Processes (LOPPE) is an obligatory reference, like the student movement of 1968 and the federal election campaign of 1988, in the discussion to mark the start point of the democratic transition in Mexico. As already indicated, Durand sets the context of the transition in its economic dimension in the mid-1970s, to date it in its political dimension in 1988. Woldenberg, noting the importance of the student mobilization of 1968, dates the beginning of the transition with the electoral reform of 1977 :

The start of the transition is in that year, not because there were no strong - and even heroic- democratizing struggles, or electoral reforms and some liberation in authoritarian arrangements, but it is from then on that the structure of change, that is to say, a process that is triggered with the strengthening of the parties and that in its moments of expansion crystallizes in negotiations that lead to new and deeper electoral reforms. In 1977, for the first time the floodgates were opened for the development of the organized options and their electoral participation. (FRIDE, 2002, p. 35)

In the same vein expressed, in their analysis of electoral competitiveness, Leonardo Valdés Zurita (1995) and Laura Patricia Romero (2004), not Farfán, for whom the 1988 elections are the time "This consciousness of change has become naturalized among us", more prospects vary and some contemplate stages and different periods. These projects include the proposed Carlos Montemayor and Macario Schettino. Thus, Montemayor presents an analysis that distinguishes three transitions: The first refers to the founding of the Revolutionary National Party in 1929, which suspended armed conflict and political negotiation mechanisms for establishing access to power; the second (1945-1952), is characterized by the predominance of civil governments, to the detriment of those headed by military; from their perspective, the third continues the peaceful transfer of power as a priority, but now through electoral competition between political parties. While Montemayor does not specify the start year of the third transition, he offers a brand: "Due to the euphoria of Vicente Fox's rise to power, we forget that for the last 70 years Mexico has actually experienced a third process of political transition, and that the essential changes did not begin with Fox, but 15 years before" (Schmidt, 2003, p. 95).

Macario Schettino, meanwhile, focuses its contribution on regime change. For him, the independent Mexico has managed to build two regimes: The first process starts in 1821 and ends in 1911; the second begins in 1920, in correspondence with the conclusion of the first transition referred Montemayor. In the same logic, it considered relevant period 1988-1997, which seems to link the democratic agitation, marked by the controversial election of Carlos Salinas and the failure of the regime, from the electoral result of 1997. In his 
words, "In 1997, the prophecy, the curse of Cosío, is fulfilled. The regime is unable to win a reasonably clean election [notice the accent on electoral cleaning] and the Chamber of Deputies remains in the hands of the opposition, divided equally between the PRD and the PAN" (Schmidt, 2003, p.129).

These analysts, as is easy to see, share a general conception based on the transition which is expressed in a series of stages, on which, however, there is no general agreement as to its beginning, the time periods covering and factors that define them. However, their differences do not eliminate its relationship with the paradigmatic model that Carothers presents. No criticism is observed to the concept of transition, it is assumed. It is not the case of Roger Bartra, for example,

Historians often use the term transition to explain the transition from a system with a more or less established structure to another system with another structure also more or less defined. However, in the current situation of Mexico we face a problem where one of the ends is loose; That is, we try to find an explanation for a process that has not yet ended. This makes things difficult. On the other hand, the notion of transition has the virtue of pointing out that we enter into an open epoch, an era of changes of something that has not worked and that can no longer be reproduced. In addition, that something is the authoritarian regime based on the revolutionary national state. However, to infer from it that it is a concept that allows us to explain a phenomenon - I insist - whose end we do not know, is a dubious claim. (Fractal, 1999, p. 2)

This argument is central and consistent with the criticism of the model and its pretensions of universality make Carothers. From this perspective, the model which ignores the socio-economic and institutional differences in the various countries has a teleological implicit in the criticism of Bartra character, as the fourth assumption expressed on behalf of an end prefigured in this speech: democracy. In this sense Lomnitz observes, at the point of arrival of the transition one of its dilemmas, because it is conceived as "the passage of an authoritarian system to a democratic system, where there is an end that is visualized as a kind of stable opening" (Fractal, 1999, p. 152).

Jorge G. Castañeda shares and applies some of the criticism and at the same time reiterates the usefulness of the concept as a tool for comparative analysis:

The main problem of comparative connotation is that it prejudices in a certain way the analysis of the process in three aspects: (1) By using the concept of transition in comparative terms, it assumed the starting point is the same everywhere. A huge historical and theoretical problem is that the PRI regime in Mexico, to put it in some way, does not fit completely with most regimes in other countries that were the starting point of the transition; (2) The concept itself and its uses not inferred if the process of change carried out in a peaceful way (as happened in most other countries) or not; and (3) The third problem is that the point of arrival seems to be the same as the points of arrival in other experiences of democratic transition. (Fractal, 1999)

You identify that the point of arrival to the Mexican experience is related to the stage of democratic consolidation. Regarding this some differences exist too, although they tend to agree that the transition period ended with the alternation in the executive branch, i.e., with the arrival to the presidency of a governor nominated by a different PRI party.

In this case, the alternation occurs in the electoral process of 2000 and is verified on December 1 - the same year with the inauguration of Vicente Fox Quezada, winning candidate nominated by the PAN in alliance with the Partido Ecologista de México (Green Party Ecologist of Mexico, PVEM).

As Durand noted, the transition covers the period 1988-2000 - the latter year is marked by the alternation. To Schettino, 2000 not only marks the time of alternation, but the issuing of the death certificate of the Revolution made by government: "El régimen de la Revolución ha muerto". 
Now the finalist character of the model can be questioned in turn in the light of the forecasts made by Jacqueline Peschard, in an interview with Murilo Kuschick, who asks: Is it possible to think eventually they will arrive in Mexico to full democracy? The answer is self-explanatory: "I am of the opinion that we are going to do it. I would not say when. The moment of alternation will be the clear signal" (Kuschick, 1996b, p. 219). What is not clear and is necessary to specify what conception of democracy referred. Farfán thinks that the type of democracy referred to is located in the electoral field:

In conclusion, the institutional consolidation of liberal democracy requires the reduction of the political to a clearly defined dimension or system within society, which implies conceiving of democracy not as a form of organization of society, but only as a type of political regime. (Schmidt, 2003, p. 27)

Woldenberg expresses a similar view, which adds what is considered to be the limits of the transition:

The Mexican transition did not lead to an unprecedented, historically unexplored regime, nor to an original constitutional invention. It moved from an authoritarian regime, which concentrated the central decisions of politics, to another, sum of renewed norms and institutions. A "democratic" system simply reached, where the vote of the ordinary citizen decides what is fundamental in politics: who governs and how the legislative bodies are composed. (FRIDE, 2002, p. 42)

It is in the field of distinction — which had been anticipated by Norberto Bobbio (2002) — between formal democracy and real democracy. The analysis can conclude that both the design of the model—as in the perspective of most of the authors cited, the concept of democracy referred to is formal and liberal, which prioritizes legal equality and opportunities - covers up the problems arising from the diversity and difference, which exists among social groups and countries to which we have tried to apply the model.

This conception, as Bobbio also pointed, promotes voter participation as the best way to influence the exercise of political power. Therefore, no wonder that the model of democratic transition, assuming the transition from dictatorship to democracy, is considered as the basic criterion holding elections and establishing new rules of the democratic game. In this regard and in relation to the Mexican case, as has already been pointed out, it does not apply the use of the name of dictatorship and electoral processes have developed continuously since the institutionalization of the revolutionary movement. What has been under constant criticism is the non-competitive nature of electoral processes even before 1988 and inequitable in relation to the provision of resources among the participating parties, the latter is recognized by President Ernesto Zedillo.

In this sense, Woldenberg, former president of the Federal Electoral Institute (IFE) under whose direction the election of 2000 was held, said that "The great initial task" of the transition was to reverse "The old and justified distrust in the electoral procedure to give it credibility and to install it as the only legitimate method of the political dispute by the positions of government and the legislature..." (FRIDE, 2002, p. 37). In this logic, it is understood that it devotes attention model to the establishment of a democratic institutional structure and its relationship with the third assumption of the model, considering that democracy equals elections, justifying the realization of successive democratic reforms.

According to observations, it seems that this is the path that ran in the Mexican case and would be expressed after demanding free and fair elections, in establishing the new rules of the democratic game. After a period of successive reforms, the legal framework would strengthen the autonomy of the IFE. From this perspective, the transition concludes with alternating effect in 2000. Meanwhile, the constitutional reform will cause multiple speeches and be marked as the goal to achieve at the stage of establishing or consolidating 
democracy. Democratic establishment is, in addition to the authoritarian dismissal, the design process, approval and implementation of the new rules of the game and it understands democratic political procedures. Usually, this step may correspond with the adoption of a new Constitution (Cansino, 2004, pp. 38-39).

While there is consensus on the importance of successive reforms, from the critical eye, it is not left to challenge the failure of the liberal conception of democracy to meet the demands of the general population and citizens "on the base" which Woldenberg concerns. For example, Durand Ponte (2004) reiterates its interest in the political dimension and its importance in democratic terms:

In this debate must be separated two times, the first is the transition from authoritarianism to democracy; the second is the consolidation of democracy as a regime. In the first the empirical evidence is not conclusive; Political development is no guarantee of the emergence of democracy, what is proven is that socio-economic development prevents the return of democracy to authoritarian regimes. (pp. 17-18)

Facing with such criticism, the response from the liberal orientation is simple and clear, as Cansino (2004) expressed:

As we know, the effectiveness of democracy to solve social and economic problems of very different magnitude is in many cases limited. Hence, performance is only one of its criteria of legitimacy. Along with it is also the aspect of the procedural character of democracy. This is the deep conviction that, through dialogue, negotiation and electoral processes, these problems find, after all, their best form of management and solution. (p. 51)

\section{Absence of Preconditions to Transition}

The fourth assumption states that the transition requires not covering specific preconditions in terms of economic level or legality of the institutions; i.e. its effect is the same from a military regime, one-party hegemonic party or a party system unconsolidated. Such an approach generally continues to generate many doubts and criticisms. In this regard they have advanced some of them, for their teleological character and difficulty of considering things - equal political life and the respective contexts. Libya, North Korea, Cuba, Chile, Brazil, Colombia, Nicaragua, Haiti and Iraq, with the Mexican case, assume that there is a need to move towards the kind of democracy that the model promotes in all these countries.

The first three countries (Libya, North Korea, Cuba) remain in an opposite ideological conception to liberal democracy; the following two military regimes (Chile, Brazil) are rallied recently and governed by parties on the left side of the electoral geometry. In Colombia it has maintained a guerrilla acting; Nicaragua and Haiti have suffered internal wars with high social cost, while the case of Iraq, under military, economic and political domination of the United States, it will be difficult in the short time to aspire to a non-tutelary democracy.

Of these cases, it may indeed argue that Brazil and Chile exemplify the fulfillment of some of the assumptions of the model, which go from a dictatorship military in this case, to the holding of free elections. An additional case would be, in this regard, Argentina. It is not to say that even accepting this fact, the validity of the review course verifies, but on the contrary, that there are specific cases to which these assumptions are applicable. You should ask if the same pattern applies to China, for example.

\section{Redesign of State Institutions}

Regarding the fifth and last assumptions presented by Carothers, who states that the democratization process is assumed to redesign state, such as the creation of new electoral institutions, parliamentary reform and judicial reform, we have already mentioned what happened in Mexico with regard to the creation of the IFE 
and the set of reforms that have been dealing with the electoral environment and have involved the creation of other bodies such as the electoral courts and changes in the form of integration of the Congress. Regarding judicial reforms beyond those related to the electoral process, the reform of the judiciary is highlighted in the period of government of Ernesto Zedillo: "A reform which, in its words, guaranteed complete autonomy and independence of the judiciary, thanks in large measure to the fact that it was agreed and approved by all parties with parliamentary representation" (FRIDE, 2002, p. 22). Further reference to the reform initiated in the state of Chihuahua and today is of general application.

These reforms, however, be considered as part of the scaffolding that supports the Mexican transition. In that sense, they don't correspond to the stage of democratic consolidation, not least from the perspective of analysts and from the speeches of representatives of political parties. Democratic consolidation is condensed in the so-called state reform and repeated calls to the drafting of a new constitution proposal, which highlights the presence of Porfirio Muñoz Ledo. Previous member of PRI, and member of the Democratic Current that split from the PRI in 1988; Previous member of PRD and former official of the administration of President Fox collaborate PRD former candidate Manuel López Obrador in the 2006 election.

However, Silva-Herzog (2004) thinks that the process has not reached safe harbor. So, from his perspective, there are many pending issues that should prevent false optimism:

When I speak of the end of the transition, I do not say or suggest that the territory we inhabit is the meager spot of "democratic normality", we do not live by any means a consolidated democracy. There remain authoritarian refuges, new fiefs of restoration and areas of misrule... Therefore, the task of our time is not a democratic system, but consolidate the precarious competitive regime that we have achieved. That is our second move: the consolidation of Mexican democracy. (p. 138)

This approach is relevant to the analysis which is performed as part of an assumption applicable to the Mexican case from two perspectives: (1) Has been appointed as the regularity of the electoral process in Mexico of institutionalized revolution and the constant triumph of the PRI in almost all elections, until the decade of the 1980s, so it could be considered as a long period when there is competition, but low competitiveness, which is considered from the perspective of who organizes and qualifies the validity election, also indicates a high level of process controlled by the traditional winners; and (2) From the perspective of the transition and considered eminently election, they could observe changes in the degree of competitiveness, to the extent that the rules of the game have changed, which in turn implies greater diversity in party political representation.

However, the positive sense that this approach can provide for assessment of the transition, should not ignore the successive adjustments between competition and competitiveness. There is no law to ensure a fair game, as Valdés (1995) states, "It may happen that a party system has fair competition rules, but that a particular election is non-competitive" (p. 29).

The transition has not been smooth and bloodless. Pretender hides loss of lives from the 1968, including the murders of party activists and the PRI candidate Luis Donaldo Colosio in 1994. The Zapatista uprising in the same year and violence against the thousands expelled from their villages and source features, explain the poverty and extreme poverty of Mexico in the 21st century, and contextualize the facts-serves to justify the application of a model that is assumed to be valid for any reality and anywhere of the world.

Before talking about democratic transition, it should be considered as a political transition. As noted by some analysts, the alternation occurs within a context of economic and political crisis. Both manifest in the 
governments of Luis Echeverria and José López Portillo. The second deepens, the PRI, with the departure of Cuauhtémoc Cardenas and Porfirio Muñoz Ledo and the political assassinations of 1994. The political sphere has been normalized. The socio-economic is still pending. Hence substantive democracy referred by Bobbio, is not the subject of analysis or discussion by various analysts and intellectuals. As César Cansino (2004) points out, "The vision of the victors, democracy is confined exclusively to the electoral question and to the party system, and is nourished by a profound contempt for the social" (p. 99).

The achievements in implementing the model are important, as are the differences shown by analyzing the Mexican case. The claim to universalize this democratic teleology does not resist the contrast. As indicated, the contexts and conditions are different and express particular historical processes. Much has been written about the democratic transition in Mexico. However, a few years ago he made a remark at a seminar on Democracy in Mexico held in Spain and has yet thought about sense. The comment by José Ignacio Wert is:

... and while academic work is still relatively modest, the dominant interpretation points to a certain over interpretation of the role that this electoral process has in the change of the Mexican political system, making see, somewhat excessively, that democracy became Mexico on July 2 of the year 2000. (FRIDE, 2002, p. 51)

If, as match some analysts (Durand, Horcasitas, Silva-Herzog, Woldenberg, Mendez Romero), social conflicts and economic conditions impact the electoral arena as a gradual liberalization mechanism managed from the federal executive branch, why the demands of social and economic issues are ignored and subordinated to the achievement of alternation? Again, Wert makes a penetrating question: "the creation of the prerequisites or conditions of equity, in the absence of a result of alternation, had done credible all work oriented to the reinvention of the Mexican political system and its definitive democratic reorientation?" (FRIDE, 2002, p. 52).

Much remains to be analyzed and one of the essential topics of study should refer to citizen participation in building democracy. According to the model tested, the formula is simple: one vote equals a citizen. In this sense, the registered voters who do not vote are not citizens. The citizen is, in this view, just a fact. It is not an agent or an actor, it is a viewer who pays with their votes, to see democratic representation in the arena of politics.

It also elucidates, what are the advantages of the party system, the functionality of the system of representation in Congress, constitutional reform and possible re-election in elected positions. It seems to be a greater willingness, not consensus. It is not so with instruments of citizen participation, which could be organized without relying on political parties. I mean independent candidates, revocation of mandate, plebiscite and referendum

The issue of transition, known and discussed, is not easy to approach if we start from different budgets to the model. As shown here, it is part of various analysis of scholars and actors of electoral politics. Make an approximation to the experience of democratic transition presented in the municipality of Juárez, Chihuahua.

\section{The Democratic Transition in Juárez}

Turnout in the municipality of Juárez, as already mentioned, was stimulated by the democratic insurgency of the 1980s, beginning the process of political change with the victory of opposition parties in major cities in the state and even, in 1992 in the state executive, after the so-called hot summer of 1986. As the results of the election by the municipal presidency of Juárez in 1983 (Table 1), the difference between the two main political 
parties is 30,586 votes $(37.3 \%)$. Inaugurating the electoral competition that leads to the alternating cycle, is buttressed with subsequent triumphs Revolutionary Institutional, followed by 11 years of government National Action until the PRI regains in 2004 the mayor with the triumph of Murguia, who at the dessert would again be elected for the period 2010-2013, defeat candidate in the electoral process 2016, and process the latter of great interest from the perspective of far treaty: the democratic transition in its liberal form, characterized by the alternation in office of popular representation.

Table 1

Election of Municipal President of Juárez, 1983

\begin{tabular}{ll}
\hline & Votes \\
\hline National Action Party & 81,940 \\
Institutional Revolutionary Party & 51,354 \\
Unified Socialist Party of Mexico & 644 \\
Socialist People's Party & 586 \\
Mexican Democratic Party & 395 \\
Socialist Workers Party & 242 \\
Revolutionary Workers Party & 114 \\
Annulled votes & 66,000 \\
Abstentionism & 95,000 \\
\hline
\end{tabular}

Reference: Lau, Jaime and Orozco (1986, pp. 24-25).

In this context, the assumption indicates that it requires no cover specific preconditions in terms of economic level or legality of the institutions to carry out the process of democratic transition. This is questioned by the economic situation prevailing in the municipality of Juárez in the 1980s, as Mizrahi (2014) said, "The economic crisis unleashed in 1982 after the nationalization of banks had in Chihuahua an electoral response" (p. 133).

So, the author says, realizing the possibilities provided the previous electoral reforms: "the novelty of this election was not only that the PAN have recognized him victories, but a significant number of entrepreneurs, especially medium and small, decided to participate actively and openly in the PAN" (p. 133). Another outstanding appearance, similar to that observed in 2016, is pointing Flores Simental (2000, n/a): "The results of the elections of July 1983 in Ciudad Juárez were a complete surprise to many, and in particular for the media".

In 1986, the winning candidate of the PAN in 1983, Francisco Barrio Terrazas, becomes a candidate for governor and in a hotly contested process, loses on suspicion of fraud against the PRI candidate Fernando Baeza Meléndez. This, as Mizrahi (2014, p. 134) argued, encourages abstentions in subsequent processes, however, the available data for the period 1977-2016 for the municipality of Juárez, realize a different process, as shown in Figure 1.

As can be seen, the highest participation rates appear to be related to episodes in which citizenship has been injured, in their either economic status or performance of politicians, their parties and/or electoral authorities. As noted, participation in 1983 is linked to the devaluation of the currency and can recognize with centralism prevailing in government decisions. In 1986, the expectation of alternation in state government promotes the participation at the local level, which decreases in 1989 as an expression of disappointment of the official result for the governorship in the previous state election, and probably by the influence of the federal 
election 1988, on suspicion of fraud. Citizenship bill comes in 1992, when the largest share $(65.1 \%)$ in the 39 years covers the period 1977-2016. The triumph of Francisco Barrio Terrazas realizes the alternation in the State Executive, the second occurred at the national level, after which took place in 1989 in Baja California, with Ernesto Ruffo Appel from the PAN.

In this sense, the highlight is that while in the national context and the federal order, the country is undergoing a process of political transition through the alternation of parties in the Presidency of the Republic, in the municipality of Juárez, and in the same State of Chihuahua, and this had already taken place in the last two decades of the 20th century.

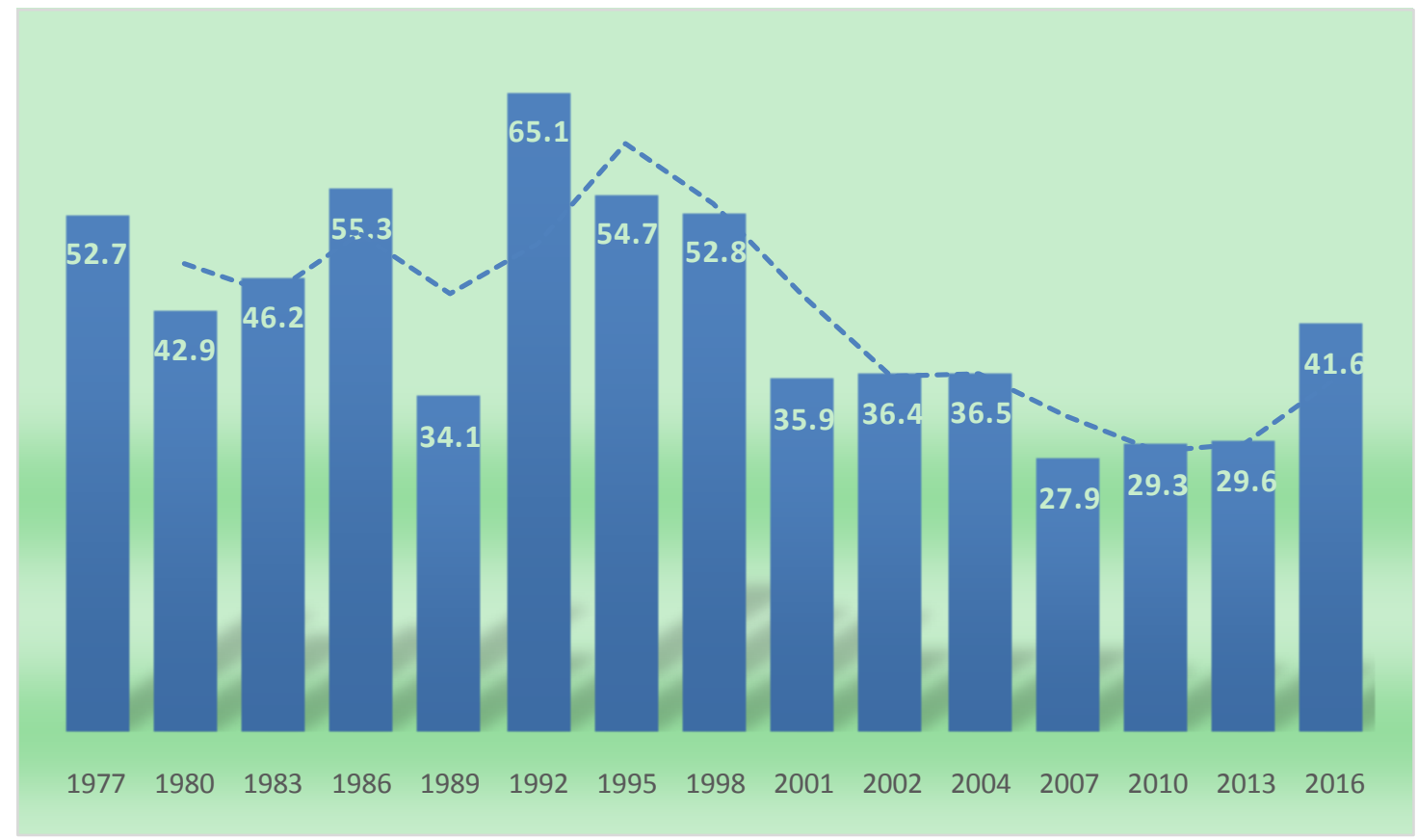

Figure 1. Percentage of citizen participation in electoral processes in the municipality of Juárez, 1977-2016. Reference: Making own with base data, Instituto Estatal Electoral (1998-2016). Padilla (2010), 1977-1995.

In the next two elections $(1995,1998)$, the share is above 50\%, dropping it, with the wear suffered by the PAN in power and under their own mistakes to $35.9 \%$ in 2001 . After cancelling the election, the PAN manages to win the extraordinary 2002 with an overall participation barely half the previous election additional percentage point. Low voter turnout has its most pronounced period 2007, with only $28 \%$ share, and 2010 and 2013, which fail to muster at least $30 \%$ of voters. One factor that qualifies the data of the last two processes indicates: extreme homicidal violence and high-impact crimes such as kidnapping, extortion, car thefts and homes with violence. In that environment, citizens go to the polls.

It notes that the largest increases in participation verified as some events do wrong to citizenship. The result of the 2016 electoral process may have some overtones of explanation in this regard. On the one hand, drawing attention to the reduction of violent acts and the most grievous crimes, the population has mostly elected representatives of the main opposition party both in relation to the Provincial Councils, as the main municipalities of the state and governor-elect in the person of Javier Corral Jurado. The City Hall of Juárez, is where one of the two independent candidates in the state of Chihuahua, obtained the victory. 
Decrease in violence, construction of roads and schools in upper middle and upper level, new community centers, implementation of the first line of multimodal transport after two failed attempts, among other achievements, are not enough for the public to offer their vote for the former mayor of Juárez, Enrique Serrano Escobar in his pretensions to win the governorship. In addition the twice-former Hector Murguia Lardizabal city for a third term is at the head of the municipality. In fact, a judgment shared by different actors indicates that even the PAN is not planned as overwhelming victory and successfully integrating their applications is not a simple exercise. In this scenario, what relationship is observed between the results of the election and democratic transition?

On the one hand, it is to recognize that the successes achieved by the opposition and in the case of Chihuahua, would not be entirely feasible with the prior institutional arrangement to successive reforms in this area which have been developed since the 1970. That is to say, the plural participation in the framework of what could be shown in accordance with a policy of liberalization that is truly stimulated, comes from various moments of social and political conflict, both nationally and in some states and municipalities. In Mexico, as already mentioned, the electoral exercise is conducted continuously since the revolution government does, although in unequal conditions and even with actions contrary to the democratic development of the country. In that sense, it highlights that in the recent history of the municipality of Juárez the electoral process in 1986, the annulment of the election of 2001 and the recent challenge to the PRI makes the process 2016.

In this regard, after the experiences of alternation in the three levels of government, it claims that the democratic transition illustrates the failure of the old regime and the emergence of a new one is clearly in doubt. On the one hand, it is clear that the model-driven economic growth in the country leads to the so-called Mexican Miracle ran out which is replaced explicitly in the 1980s and 1990s, however this does not change the political regime, but is also in crisis. Thus, the creation of the IFE, now the Instituto National Electoral (INE), made progress in establishing new rules of the democratic game, it is questioned by his obvious partisanship. One indicator of this is the questioned processes of 2006 and 2012, which has even recognized that practices with a critical eye, put on trial the principles of certainty, transparency, objectivity and legality that should underpin the activities which were conducted of the electoral bodies.

In this regard, Pacheco (2010) realizes the idea of Juarez residents about of the electoral processes after having experienced the alternation. It is interesting to observe how some members of political parties are in the light of the questions that have occurred after the defeat of the PRI in 2016. For example, a zone coordinator of the PRI, 53 expressed in 2008, he states:

Then... that is the worst that exists in parties, groups of power, it is assumed that it should be, all, all we have to be institutional, what party mark is what must be done. In addition, no, this is otherwise, in all parties is the same. There are power groups, and logically extending the payment, when groups of power, then already are moored the municipal Presidents, Governors, remain tied, then because nothing else give them privileges to those small groups. Which are groups of power, groups of very strong capital, and the poor people, humble people is leave it aside, only just use it when there are campaigns and when they already get to power to people close the doors. That, that, that is what inhibits the vote. (Pacheco, 2010, p. 241)

In the same sense another man of 63 years, PAN promoter manifests itself:

It is exactly what said you, distrust, that... the vote do not assert. Do not use because, because it is no good to vote because they do not comply, no good right now to vote. If when they do the campaigns do promise, and then coming to power then when already. Why people become disillusioned it and stop voting; and better right now the voter credential 
comes already as a requirement to exercise the person, and I will tell you himself... as a requirement, as a card, and use it as a credential, for purposes of the person, such as identification, rather for that serves you today. (Pacheco, 2010, p. 242)

In this vein, we can assume that democracy equals elections, becoming the key to the successive democratic reforms, which first involves analyzing what assessment the same citizenship of these practices has. In this regard, please note Figure 2, which accounts for the percentage of abstention in the period 1977 to 2016. In this regard, it is worth noting that the assumption that is not required for the democratic transition, covers specific preconditions in economic level or legality of the institutions, and that the economic growth of the municipality has not had relevant social development policies, heedless population groups such as children, youths, and older adults. It has stimulated the creation of organizations of civil society and business participation in community intervention work to alleviate some of the problems that have been present and brought out in the period of recent violence.

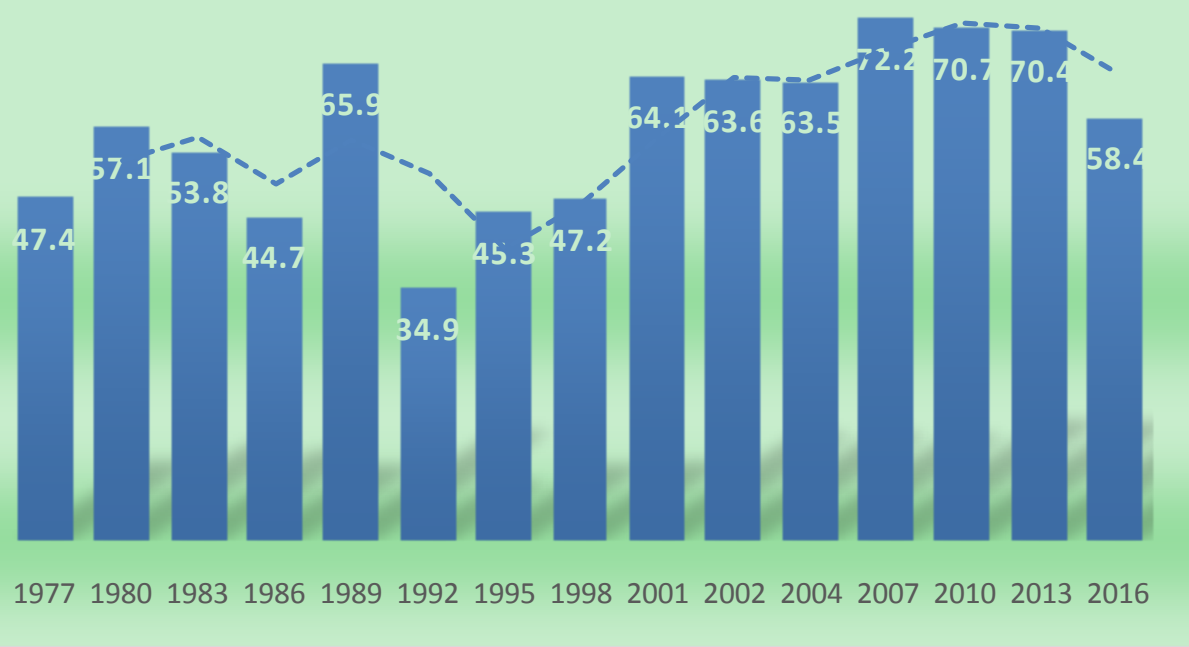

Figure 2. Electoral abstentionism in electoral processes 1977-2016 Municipality of Juárez, percentages.

Reference: Making own with base data, Instituto Estatal Electoral (1998-2016). Padilla (2010), 1977-1995.

Thus, the challenge to the PRI hegemony and successive electoral reforms leads to greater competition with the incorporation of business groups and sectors of organized citizens in civil associations of different sign. In the 2016 elections, unlike previous processes, that the social agenda has no place and even the wage condition of the labor force in the maquiladora industry contracted before being relegated, is cause for attention in the speeches of the various candidates. In fact, an avowedly business candidate José Luis Barraza Gonzalez, rises to the political arena as a nonparty candidate, achieving third place in the vote.

Corral victory for governor, seems to respond to those needs ignored beyond the discursive and the demand for transparency. In this regard, a trace in the past, says Flores Simental, Barrio Terrazas, the protagonist of alternation in Chihuahua when runs for mayor in 1983: "In contrast to other candidates, neighborhood not made promises during his campaign. His speeches were basically attacks on official corruption and the economic crisis". Corral in 2016, focuses his speech on corruption, which gives the governor of the state, and brings him to justice. In addition, it achieves an alliance with movements and civil society organizations as well as representatives of business sector. For its part, the triumph of Cabada in the 
municipality of Juárez, as a candidate without party for mayor, member of the owning family of concessions in the TV spectrum and known news anchor, realizes the distrust of citizens in political and their parties, as stated in 2008 a woman of 43 years, despite the judgments express,

We voted by the person that believe that going to be the best ruler, that goes to work best by the city. Then comes "oh disappointment", that does not work for the city, work by a group of people. Because if it is ruling the bread, it works to a certain group of people; if it is ruling the PRI, he worked for another. As if right now that it is ruling the PRI, to us that once we belong to the PAN, is that not even who are you. That is not a level Juárez, is national, Juárez is not to level. Because I have discussed with people from other States and it is the same (Woman, 47 years old, voter). (Pacheco, 2010, p. 260)

In the recent municipal elections, parties were relegated by citizens who chose not to reiterate its support for a political twice mayor. He did not accept either, Virginia Caraveo Vallina, PAN candidate and activist against violence against women. So far, the choice seems to realize that the democratic transition has resulted in a municipal area. There has been a fair electoral process-beyond the puny challenge PRI, with greater citizen participation in the last 15 years, has been elected a candidate without party and his body elected aldermen are also mostly non-party citizens. His campaign speech refers to its commitment to the most disadvantaged; to co-govern with social organizations and business chambers sectors. Envisions and has declared a possible re-election in 2018. It is by analysis on its success can be attributed to negotiation with the main political parties, which led to the so-called crossover voting that allowed Corral get the governorship and inside the PRI has unleashed a series of questioning around party loyalty. Thereafter you can argue whether these results point to a regime change and a reconceptualization of democracy in the framework of alternation, so far privileged expression of the transition in Mexico.

\section{Conclusion}

As it shown, the democratic transition model evidences its failures by subjecting it to contrast with the Mexican experience. In the first instance, the Mexican regime cannot be considered as dictatorial. As the aforementioned authors argued, it is corporate and still authoritarian. From the 1980s decade of the 20th century, there have been several periods where there have been various electoral political conflicts, having as background the economic crisis that manifested itself in an indisputable way at the end of the term of José López Portillo and Pacheco. In this sense, the relations that economic conditions have with the emergence of citizen mobilizations and political leaderships, even as divisions of the hegemonic party, as in the Mexican case, cannot be ignored.

One of the results of the democratic emergency involved the establishment of a new electoral institution, not administered by the federal government, and through successive electoral reforms, new rules of the game. In practice, these have ceased to have a specific weight in the establishment of a democratic regime, while its members appointed through negotiations by the three dominant political parties. A new constitution has not been necessary and the elections have been regular, which does not mean that they have not been recurrently challenged.

The existence of numerous political parties and the regularity of electoral processes can be considered as indicators of a democratic progress, especially if the formula "democracy equals elections" followed. In the local case presented, a pioneer in political alternation, the levels of electoral abstention indicate that for broad sectors of the citizenry democracy didn't reduce to this practice. In this sense, democratic transition, or rather 
political alternation, is not a point of arrival, but an opportunity to broaden and deepen the democratic exercise in favor of substantive democracy, one that transcends the liberal and procedural conception, giving priority to attention of social problems.

\section{References}

Bayón, M. C. (2006). Precariedad social en México y Argentina: Tendencias, expresiones y trayectorias nacionales. Revista de la CEPAL, 88, 133-152. Retrieved from http://www.eclac.org/publicaciones/SecretariaEjecutiva/9/LCG2289PE/ G2289eBayon.pdf

Bobbio, N. (2002). Liberalismo y democracia. México: Fondo de Cultura Económica.

Cansino, C. (2004). El desafío democrático. La transformación del Estado en el México postautoritario. México: CEPCOM, 2004.

Carothers, T. (2002). The end of the transition paradigm. Journal of Democracy, 13(1), 5-21.

Dahl, R. A. (1996). La poliarquía. Participación y oposición. México: REI.

Durand Ponte, V. M. (2004). Ciudadanía y cultura política: México, 1993-2001. México: Siglo XXI Editores.

Farfán, H. R. (1996). Del paradigma político de la transición. Estudio crítico de un modelo de análisis político. Sociológica, 30, año 11 , enero-abril.

Flores Simental, R. (2000). El papel de los medios en la campaña electoral de 1983 en Ciudad Juárez, Chihuahua. Razón y Palabra, 17. Retrieved from http://www.razonypalabra.org.mx/anteriores/n17/17rflores.html

Fractal. (1999). Discusión: La transición, esa metáfora calva. Fractal, 4(12), 151-167. Retrieved from http://www.fractal.com.mx/F12vario.html

Fundación para las Relaciones Internacionales y el Diálogo Exterior (FRIDE). (2002). La democracia en México. Seminario sobre Transición y Consolidación Democráticas 2001-2002, 13 y 18 de diciembre de 2001. Madrid: FRIDE.

Instituto Federal Electoral. (2010). ¿Qué es el instituto federal electoral? Retrieved from http://www.ife.org.mx/InternetCDA/MenuSuperior/index.jsp

Kuschick, M. (1996a). México en la transición democrática. Entrevista a Jacqueline Peschard. Sociológica, 30, año 11, enero-abril.

Kuschick, M. (1996b). Entrevista con Juan Molinar Horcasitas. Sociológica, 30, año 11, enero-abril.

Lau, R., Jaime Flores, V., \& Orozco, V. (1986). Sistema político y democracia en Chihuahua. México: Instituto de Investigaciones Sociales, Universidad Nacional Autónoma de México y Universidad Autónoma de Ciudad Juárez.

Mizrahi, Y. (2014). Las elecciones en Chihuahua. Retrieved June 15, 2014, from http://biblio.juridicas.unam.mx/libros/4/1761/12.pdf

O'Donnell, G., Schmitter, P. C., \& Whitehead, L. (Eds.). (1988). Los procesos de transición y consolidación democrática en América Latina. Buenos Aires: Paidós.

Pacheco González, S. (2010). Las razones del abstencionismo. In P. Delgado, \& H. Antonio (coord.), Para mí es lo mismo. Causas del abstencionismo en Ciudad Juárez (pp. 237-277). Ciudad Juárez, Chihuahua: Universidad Autónoma de Ciudad Juárez, 2010.

Rodríguez Alonso, J. (1999). Hacia nuevos actores e instituciones. In A. Sánchez, J. Rodríguez Alonso, et. al. (coord.), Las instituciones para la democracia en México (pp. 95-102). México: Instituto Federal Electoral.

Romero, L. P. (2004). Autoritarismo con nuevo rostro o fragilidad democrática en Jalisco: Espiral. Estudios sobre Estado y Sociedad, 10(30), 65-81.

Sánchez Zazueta, J. (2008). Reflexión sobre el ethos ciudadano y los estudios sobre corrupción. Revista Politeia, 26 , 9-24.

Schettino, M. (2003). La crisis de México, medio siglo y un lustro después. In S. Schmidt (coord.), La nueva crisis de México (pp. 127-130). México: Nuevo Siglo Aguilar.

Schmidt, S. (coord.). (2003). La nueva crisis de México. México: Nuevo Siglo Aguilar.

Silva-Herzog Márquez, J. (2004). El antiguo régimen y la transición en México. México: Editorial Planeta Mexicana/Joaquín Mortiz.

Valdés Zurita, L. (1995). El sistema de partidos en México: las dimensiones de la competitividad electoral. Política y Cultura, 5, 29-41. Retrieved from www.xoc.uam.mx/ polcul/pyc05/29-41.pdf 